\title{
A study of composition and diversity variation of avifauna along with different types of agroforestry system in Kibet town, Southern Ethiopia
}

\author{
Hussen Yasin ${ }^{1}$ and Wondimagegnehu Tekalign ${ }^{2^{*}}$ (D)
}

\begin{abstract}
Background: Agroforestry is an integrated land-use system that plays a great role in the conservation of landscape biodiversity. The study aimed to assess the composition and diversity of avian species along with different habitat types of agroforestry in Kibet Town, Southern Ethiopia.

Methods: Four habitat types of agroforestry system which are home gardens, live fences, parkland, and eucalyptus woodlot were identified. Line transects were used for bird surveys. The Shannon diversity index $\left(H^{\prime}\right)$ and species evenness index (E) were used to compare diversity among habitat types. A similarity percentages (SIMPER) test was carried out to identify the main species and feeding guild that typified each habitat type. The overall significance was assessed with the ANOSIM test using PAST (version 4.03).

Results: A total of 50 bird species belonging to 28 families and 10 orders were recorded. Order Passeriformes (67.3\%) had the highest number of species. Bird community composition differed among habitat types. The dissimilarity was mainly due to White-browed robin-chat (Cossypha heuglini), Streaky seed-eater (Serinus striolatus), Village Weaver (Ploceus cucullatus), African Paradise-Flycatcher (Terpsiphone viridis), and Black-Headed Paradise Flycatcher (T. rufiventer). The finding also revealed that insectivore was the dominant feeding guild.

Conclusions: The present study shows evidence that more insectivore bird species use different types of agroforestry as habitat and foraging sites. So, any concerned bodies who have engaged in avian conservation should give special consideration to this modified landscape.
\end{abstract}

Keywords: Agroforestry, Avifauna, Feeding guilds, Insectivores, Kibet Town, Land-use

\section{Introduction}

Agriculture is a major manipulator of biodiversity but also has the potential to contribute to the protection of biodiversity [18]. To advance conservation and production goals, agricultural practices should be compatible with biodiversity [31]. The negative effect of agricultural

\footnotetext{
*Correspondence: wondimagegnehubeyene@gmail.com

${ }^{2}$ Department of Biology, College of Natural and Computational Sciences, Wolaita Sodo University, PO Box 138, Wolaita Sodo, Ethiopia
}

Full list of author information is available at the end of the article systems on biodiversity has been reached to a large extent in this century due to the use of unsound technologies, inadequate zoning and farming practices and, mechanization, and deforestation [2]. Agroforests and other agricultural habitats rich in tree cover are essential for connecting isolated protected areas and their metapopulations [33]. Agroforestry is the most possible landuse system to raise tree cover and help conservation [9]. It is recognized as a possible partial solution for biodiversity conservation and improvement [41]. It improves 
biodiversity as it provides more habitats and food for birds, small mammals, reptiles, earthworms, and insects, which in turn lead to an increase in species diversity as a whole [1].

Agroforestry is recognized as an integrated land-use that can directly enhance agro-biodiversity and contribute to the conservation of landscape biodiversity, while at the same time increasing, diversifying, and sustaining rural incomes [24,39]. It is a production system characterized by the combination of forestry and agriculture [42]. Many landowners view wildlife as an important byproduct of their land management activities, particularly wood production [43]. The role of agroforestry practices on the provision of environmental services, particularly their contribution towards biodiversity conservation, recently attracted wider attention among field scientists [25].

In Ethiopia, agroforestry adoption like cash trees among small farms helps farmers to improve and recover the rural farmland management system and to maximize the farm productivity and income [11, 21]. It is an alternative and probably cheaper option for agricultural intensification and sustainability in the country. Different agroforestry practices are identified in the country as per their suitability to the different agro-ecology $[7,10,26]$.
In Ethiopia, bird diversity and abundance in protected areas and natural forests have been studied by many national and international researchers, but the role of agroforestry for the conservation of wildlife in general and avian diversity, in particular, is still not studied in many parts of the country. Furthermore, nowadays to assess the response of species to emergent landscape characteristics is very crucial. Hence, this study was aimed to assess the composition and diversity of avian species along with the different types of agroforestry in case Kibet Town, Southern Ethiopia.

\section{Methods and materials}

\section{Study area and site selection}

The study was conducted in Southern Ethiopia, Silte zone, Kibet town agroforestry system (Fig. 1). The town is located $148 \mathrm{~km}$ from Addis Ababa on the road between Butajira to Arabaminch. It is $173 \mathrm{~km}$ far from Hawassa and $26 \mathrm{~km}$ from Werabe the capital towns of the Region and Zone, respectively. Its geographical location is approximately at $07^{\circ} 56^{\prime} \mathrm{N}$ and $38^{\circ} 14^{\prime} \mathrm{E}$. Its mean annual temperature is $18.8^{\circ} \mathrm{C}$ and its annual rainfall pattern is $1200.5 \mathrm{~mm}$ which is the climatic data of the closest town of Butajira since there is no available data for the district [15].

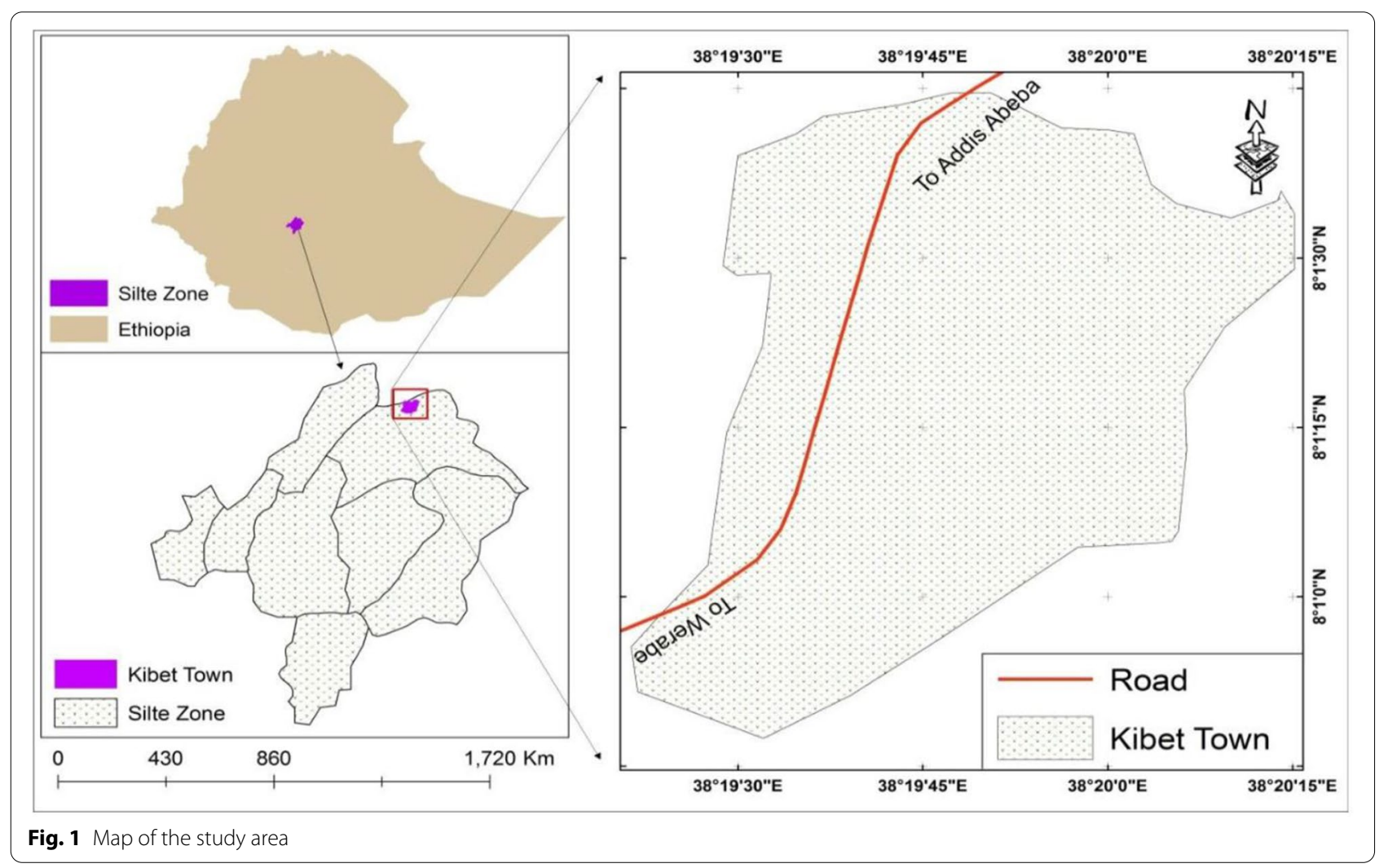


The agroforestry system in the study area mainly consists of the chat (Catha edulis), coffee (Coffea arabica L.), and Enset (Ensete ventricosum). Fruit trees such as Sweet orange (Citrus sinensis L.), Lime (Citrus aurantifolia), Avocado (Persea Americana Mill), Mango (Mangifera indica L.), and Banana (Musa paradisiacal L) are common. Unlike chat and coffee, fruits and vegetables are produced for consumption and local market. There are also several multipurpose tree varieties such as Tid (Juniperus procera), Zigba (Podocarpus gracillor), Weira (Olea Africana), Sholla (Fiscus gur), Bisana (Croton macrostachyus), Wanza (Cordia africana), and different Acacia spp. provide various services including fuelwood.

The vegetation cover of the field within the survey area was mapped during the bird survey. Fields were classified into four categories in terms of their field vegetation cover. These are home gardens, live fences, parkland, and fast-growing eucalyptus woodlots.

Home gardens $(\mathrm{Hg})$ are composed of a high diversity of plants and an important source of household subsistence and cash needs which are characterized by being near the residence. The dominant components of the home gardens are coffee, enset, pepper, various annual crops, and numerous kinds of vegetables.

Live fences (Lf) are barriers of closely spaced trees or shrubs to protect crops or structures against livestock and human interference. It may be established all around the farm, but it is commonly established around the homesteads and gardens. Plant species like Koshim (Dovyalis abyssinica) are common native tree species to be promoted for this purpose other such as Qentaffa (Pterollobium stellatum), Quelqwal (Euphorbia abyssinia), and Acacia spp.

Eucalyptus woodlot (Ew) where woody perennial is planted and managed over time to produce fuelwood, and poles. The most common eucalyptus is the Eucalyptus globulus.

Parkland (Pl) involves the growth of individual trees and shrubs in wide spaces in croplands. Some good examples of this practice are Cordia africana and Acacia albida intercropping with maize.

\section{Study design}

The study was conducted from December 2019 to early October 2020 encompassing both wet and dry seasons. We assigned four study sites that reflected the impact of changing agroforestry type on bird diversity in the Kibet town agricultural landscapes. Fifteen sampling sites were established encompassing four study sites (habitat types): Home gardens $(\mathrm{Hg}, n=5)$, Live fences ( $\mathrm{Lf} n=4)$, Eucalyptus woodlot (Ew, $n=3$ ), and Parkland ( $\mathrm{Pl} n=3$ ). We established a line transect in each sampling site with 500$700 \mathrm{~m}$ in length [8]. Each line transect was $100 \mathrm{~m}$ far away from the roadside to avoid edge effect and $300 \mathrm{~m}$ far away from each other to avoid double counting of the same individual of a species following the work of [6].

Feeding guilds were classified based on direct observations and available literature on feed bioecology [16].

\section{Sampling method}

Data were collected from December 2019 to April for the dry season and from late May to early October 2020 for the wet season. Four field visits (two visits in dry season and two visits in wet season) were conducted to observe the composition and diversity of bird species. Line transects were surveyed in each sampling site and pooled the data for analysis. The transect line was walked at a constant pace for approximately $30 \mathrm{~min}$. Species observation mostly took place through vision and also through acoustic.

\section{Bird survey}

In all transects walk at a steady pace $(30 \mathrm{~min})$ between 7:00 am and 9:00 am in the morning and $4: 30 \mathrm{pm}$ to $6: 00 \mathrm{pm}$ in the late afternoon when most birds are active [6]. In the home garden area footpaths were used. To minimize disturbance during the count, a waiting period of 3 to $5 \mathrm{~min}$ before counting was applied [40]. No count was conducted in the presence of passing vehicles [28]. Species observation mostly took place through vision by using $8 \times 17$ binoculars and eyes, but also through sound. Overflying species were not included in the count.

Identification was visual except in some rare cases when the voice will be used if the bird cannot be seen. Identification and categorization of birds to their respective taxonomic groups' done following field guide books $[4,46,47]$. By considering all the recorded species during the study period, a baseline of bird checklist (database) was prepared.

\section{Data analysis}

Different samples of each habitat were pooled before analysis. Data were analyzed using the ShannonWeaver Index to determine the species diversity and evenness in the study area [35]. A similarity analysis (SIMPER) was carried out to calculate the percentage contribution of each bird species to different study sites (i.e., species that are characteristic of each habitat type) along with the agroforestry system. But only the three most contributing species were considered for dissimilarity comparison. Differences in feeding guilds (in terms of feeding functional group) similarity between habitat types were also described by SIMPER and a one-Way Analysis of Similarity (ANOSIM). ANOSIM is a non-parametric permutation test that uses similarity matrices or, in this case, the Bray-Curtis 
index [13]. When there are no group differences global $R$ is centered at zero, or $R \leq 0$, whereas if there are high group differences $R=1$ [37]. Additionally, differences in species composition among sites were analyzed by a non-metric multidimensional scaling (NMDS), using the Bray-Curtis index. The species data can be collapsed into two dimensions using this ordination technique [30]. A plot of NMDS was applied as a visual aid to interpreting how species composition differed among habitat types [23]. The ANOSIM and SIMPER test was carried out with PAST 4.03 [20].

\section{Results}

A total of 50 bird species were recorded in the study area under 10 orders and 28 families. Order Passeriformes (67.3\%) had the highest number of species followed by order Columbiformes $(8.16 \%)$ while the lowest number of species was recorded under the order Bucerotiformes, Psittaciformes, and Coliiformes each represented with one species (Fig. 2). Out of the total recorded of avian species, $36 \%(n=18)$ were residents, $34 \%(n=17)$ wet season visitors, and $30 \%(n=15)$ were dry season visitors (see Additional file 1). Two endemic bird species of Ethiopia namely Wattled Ibis (Bostrychia carunculata) and Black-winged Lovebird (Agapornis taranta) were identified from the study area.

Species diversity and evenness indices showed a nearly similar value for each corresponding index among different habitat types. The value of the Shannon-Weiner diversity index $\left(\mathrm{H}^{\prime}\right)$ of these four habitat types (viz. Lf, $\mathrm{Ew}, \mathrm{Hg}$, and $\mathrm{Pl})$ was greater than $1\left(\mathrm{H}^{\prime}=1.098,1.093\right.$, 1.092 , and 1.035, respectively). There was an even dispersal and distribution of species among sampling habitats viz. Lf, $\mathrm{Hg}$, Ew, and $\mathrm{Pl}(\mathrm{J}=0.999,0.994,0.995$, and 0.942, respectively) based on Pielou's evenness index (J) value (Fig. 3).

\section{Habitat wise bird species dissimilarity}

Regarding bird species similarity among habitat types, the result of similarity percentages (SIMPER) analysis and analyses of similarity (ANOSIM) are shown in Table 1 . The dissimilarity between $\mathrm{Hg}$ and Lf was mainly linked to White-browed robin-chat (Cossypha heuglini) and Streaky seed-eater (Serinus striolatus) with a $60.45 \%$ dissimilarity level. For the dissimilarities of the two pairs: $\mathrm{Hg}$ vs $\mathrm{Ew}$ and $\mathrm{Hg}$ vs $\mathrm{Pl}$, four main species were contributing more to the average dissimilarity. In particular, the presence of Village Weaver (Ploceus cucullatus) and Red-cheeked Cordonbleu (Uraeginthus bengalus) in $\mathrm{Hg}$ contributed more than $30 \%$ to the average dissimilarity. In group pairs, Lf vs Ew and Lf vs Pl, White-browed Robin-Chat (Cossypha heuglini), Streaky seed-eater (Serinus striolatus), and Village Weaver (Ploceus cucullatus) contributed most to the dissimilarity between the two group pairs. In the cases of group $\mathrm{Ew} v \mathrm{vs}$, the main species contributing to the dissimilarity include African Paradise-Flycatcher (Terpsiphone viridis), Black-Headed Paradise Flycatcher (Terpsiphone rufiventer), and Village Weaver (Ploceus cucullatus) contributed most to the dissimilarity (more than 40\%) (Table 1).

As the one-way ANOSIM result shows that the global $R$-value for most group pairs is 1 . This suggests that there is group separation between these group pairs. In the cases of groups $\mathrm{Hg}$ vs Lf, the global $R$-value is 0.5 . The highest group separation with global $R=1$, occurring among the corresponding group pairs: $\mathrm{Hg}$ vs Ew, $\mathrm{Hg}$ vs $\mathrm{Pl}$, Lf vs Ew,

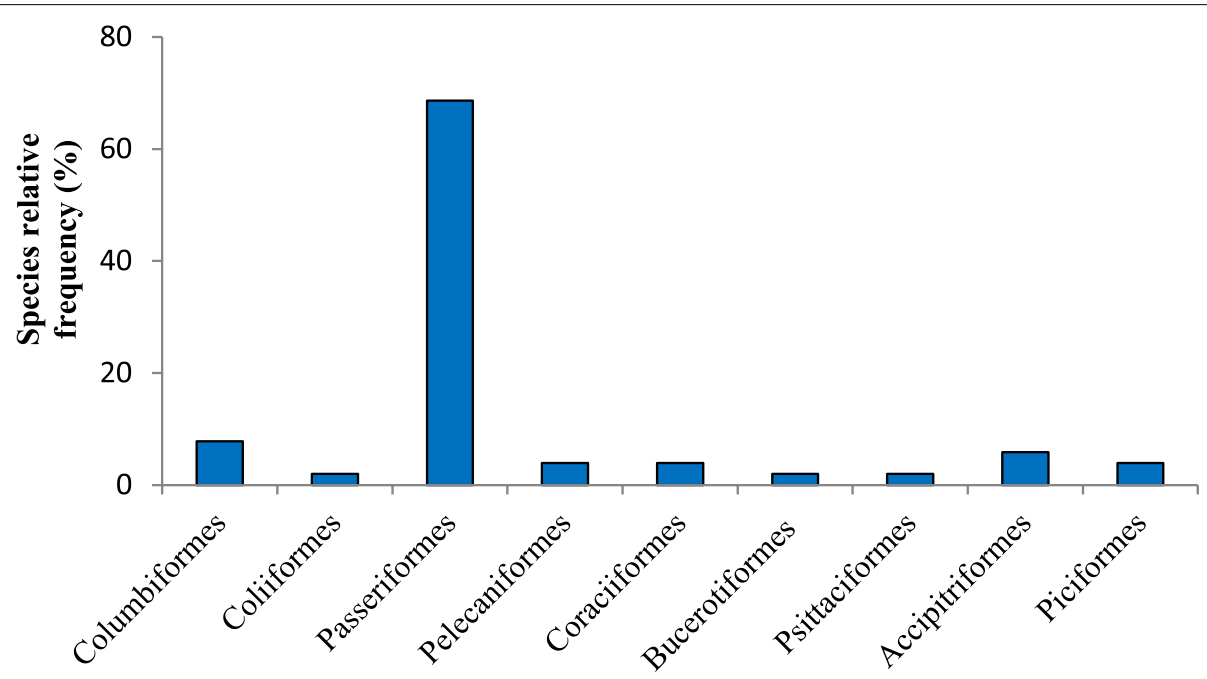

Fig. 2 Species composition of birds in their respective orders 


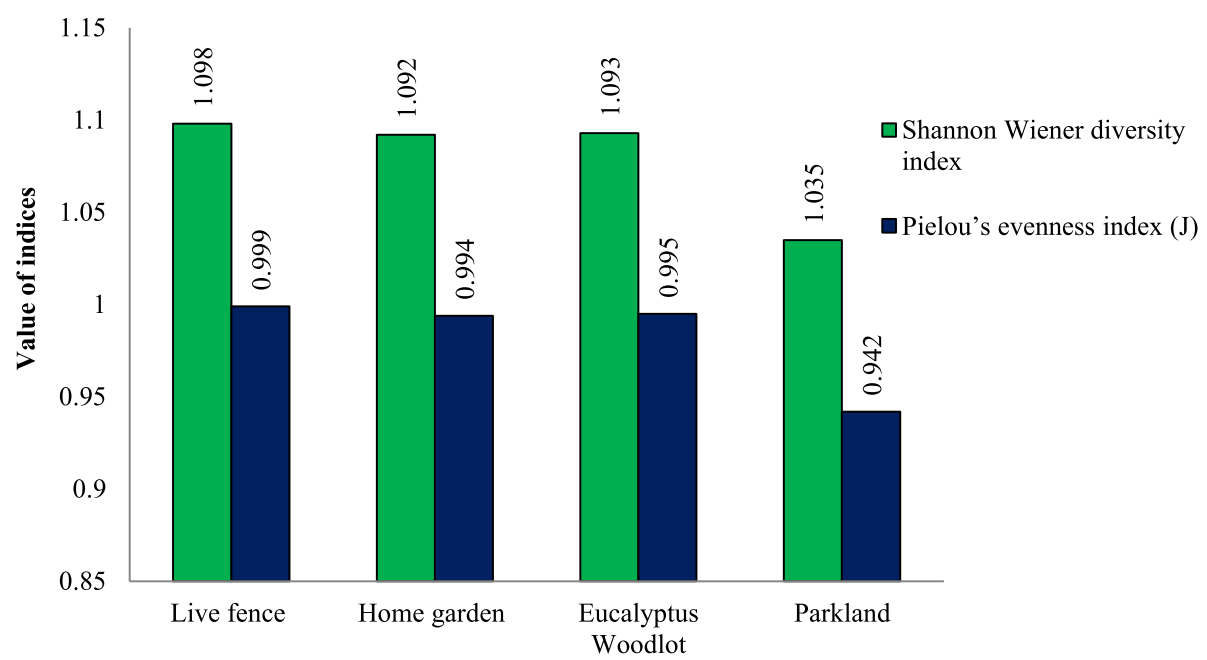

Fig. 3 Variation of Shannon's diversity index and Pielou's evenness index $(J)$ along with different habitats type of the study area

Table 1 SIMPER and ANOSIM results for the pooled data of bird community composition between habitat pairs among the four habitat types (viz. Hg, Lf, Ew, and PI) are presented

\begin{tabular}{|c|c|c|c|c|c|c|}
\hline \multirow[t]{2}{*}{ Habitat types } & \multicolumn{4}{|l|}{ SIMPER } & \multicolumn{2}{|c|}{ ANOSIM } \\
\hline & Most discriminating species & Contrib (\%) & Cum (\%) & $\begin{array}{l}\text { Over. Av. } \\
\text { Dissimilarity }\end{array}$ & $R$ & $p$ \\
\hline \multirow[t]{3}{*}{ Hg vs Lf } & White-browed Robin-Chat & 19.5 & 19.5 & 60.45 & 0.5 & 0.6634 \\
\hline & Streaky seed-eater & 12.24 & 31.75 & & & \\
\hline & White-rumped Babbler & 8.155 & 39.9 & & & \\
\hline \multirow[t]{3}{*}{ Hg vs Ew } & Village Weaver & 19.1 & 19.1 & 86.62 & 1 & 0.3302 \\
\hline & Red-cheeked Cordonbleu & 15.45 & 34.55 & & & \\
\hline & Yellow spotted Petronia & 7.516 & 42.07 & & & \\
\hline \multirow[t]{3}{*}{$\mathrm{Hg}$ vs $\mathrm{Pl}$} & Village Weaver & 17.49 & 17.49 & 89.85 & 1 & 0.3333 \\
\hline & Red-cheeked Cordonbleu & 14.14 & 31.63 & & & \\
\hline & Yellow spotted Petronia & 6.841 & 38.47 & & & \\
\hline \multirow[t]{3}{*}{ Lf vs EW } & White-browed Robin-Chat & 17.11 & 17.11 & 89.59 & 1 & 0.3277 \\
\hline & Streaky seed-eater & 10.7 & 27.81 & & & \\
\hline & Village Weaver & 8.009 & 35.82 & & & \\
\hline \multirow[t]{3}{*}{ Lf vs $\mathrm{PI}$} & White-browed Robin-Chat & 15.82 & 15.82 & 93.3 & 1 & 0.3344 \\
\hline & Streaky seed-eater & 9.901 & 25.72 & & & \\
\hline & Village Weaver & 6.905 & & & & \\
\hline \multirow[t]{3}{*}{ Ew vs PI } & African Paradise-Flycatcher & 16.54 & 16.54 & 49.79 & -0.25 & 0.668 \\
\hline & Black-Headed Paradise Flycatcher & 13.01 & 29.55 & & & \\
\hline & Village Weaver & 12.73 & 42.28 & & & \\
\hline
\end{tabular}

Only three species that contributed the most to the dissimilarity are shown. The average dissimilarity is the contribution of each species to the dissimilarity between the two groups according to Bray-Curtis similarity. Contribution \% indicated the contribution of each species to the group pair dissimilarity in percentage values. Cumulative $\%$ indicates the cumulative value of the contribution of each species to the dissimilarity

Contrib \% Percentage contribution, Cum\% Cumulative contribution, Over. Av Overall average dissimilarity, $R$ Global $R$-value, $P$-value Significant value $<0.05$

and Lf vs Pl. However, in all cases at $p$-value $>0.05$ the separation is not significant (Table 1). In support of this test, the Non-metric multidimensional scaling (NMDS) ordination technique also showed close clustering of study sites ( $\mathrm{Hg}, \mathrm{Lf}, \mathrm{Ew}$, and $\mathrm{Pl}$ ) based on species presenceabsence among study sites with a 0.09 stress (Fig. 4). 


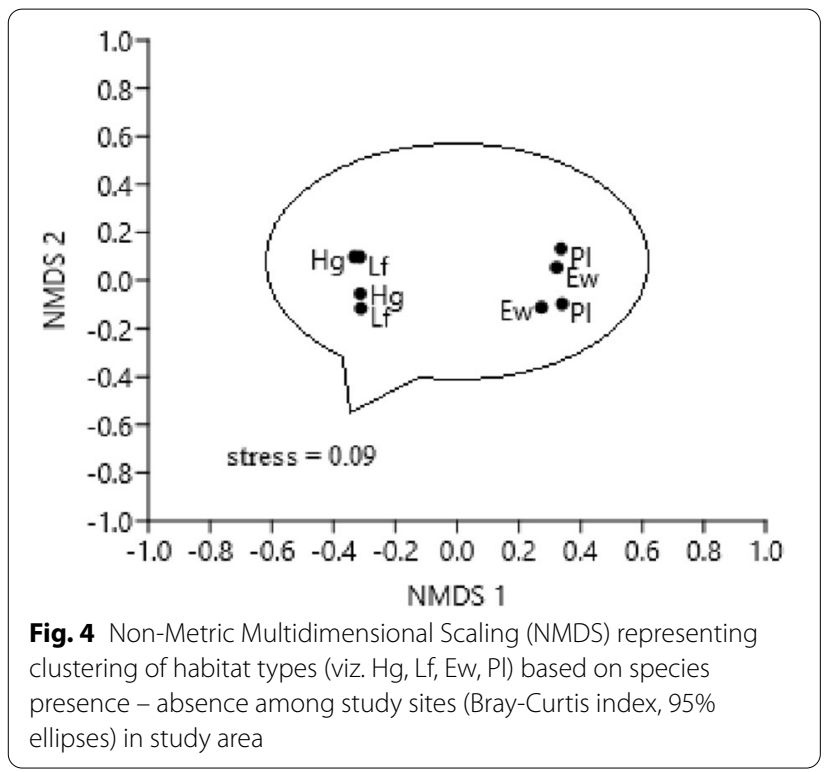

Table 2 SIMPER and ANOSIM results for the pooled data of bird feeding functional group between habitat pairs among the four habitat types (viz. Hg, Lf, Ew, and PI) are presented

\begin{tabular}{|c|c|c|c|c|c|c|}
\hline \multirow[t]{2}{*}{ Habitat types } & \multicolumn{4}{|l|}{ SIMPER } & \multicolumn{2}{|c|}{ ANOSIM } \\
\hline & $\begin{array}{l}\text { Most discriminating } \\
\text { feeding guild }\end{array}$ & Contrib (\%) & Cum (\%) & Over. Av. Dissimilarity & $R$ & $p$ \\
\hline \multirow[t]{3}{*}{ Hg vs Lf } & Insectivores & 58.06 & 58.06 & 43.64 & 0 & 0.6702 \\
\hline & Granivores & 20.4 & 78.46 & & & \\
\hline & Nectarivores & 10.84 & 89.31 & & & \\
\hline \multirow[t]{4}{*}{ Hg vs Ew } & Granivores & 52.18 & 52.18 & 62.72 & 1 & 0.3298 \\
\hline & Insectivores & 20.78 & 72.96 & & & \\
\hline & Nectarivores & 11.38 & 84.34 & & & \\
\hline & Frugivores & 10.27 & 94.61 & & & \\
\hline \multirow[t]{4}{*}{$\mathrm{Hg}$ vs $\mathrm{Pl}$} & Granivores & 48.86 & 48.86 & 75.04 & 1 & 0.3314 \\
\hline & Carnivores & 15.97 & 64.84 & & & \\
\hline & Insectivores & 12.65 & 77.48 & & & \\
\hline & Nectarivores & 10.71 & 88.2 & & & \\
\hline \multirow[t]{2}{*}{ Lf vs Ew } & Insectivores & 50.49 & 50.49 & 56.25 & 0.5 & 0.3442 \\
\hline & Granivores & 35.65 & 86.14 & & & \\
\hline \multirow[t]{3}{*}{ Lf vs PI } & Insectivores & 47.19 & 47.19 & 79.06 & 1 & 0.3319 \\
\hline & Granivores & 28.4 & 75.59 & & & \\
\hline & Carnivores & 11.08 & 86.67 & & & \\
\hline \multirow[t]{4}{*}{ Ew vs PI } & Insectivores & 28.92 & 28.92 & 68.54 & 0.75 & 0.3412 \\
\hline & Carnivores & 26.53 & 55.45 & & & \\
\hline & Frugivores & 21.84 & 77.29 & & & \\
\hline & Omnivores & 11.77 & 88.06 & & & \\
\hline
\end{tabular}

Dissimilarities between pairs of groups and bird feeding guild contributions are indicated. The average dissimilarity is the contribution of each feeding guild to the dissimilarity between the two groups according to Bray-Curtis similarity. Contribution \% indicated the contribution of each feeding guild to the group pair dissimilarity in percentage values. Cumulative \% indicates the cumulative value of the contribution of each feeding guild to the dissimilarity. Only functional feeding groups that contributed the most (>10\%) to the dissimilarity are shown

Contrib\% Percentage contribution, Cum\% Cumulative contribution, Over. Av Overall average dissimilarity, $R$ Global $R$-value, $P$-value Significant value $<0.05$

\section{Bird functional feeding group along with different habitat types}

Out of 50 species recorded in this study, the highest $40 \%$ were insectivorous, followed by granivorous (18\%), nectarivorous (9\%), omnivorous (8\%) carnivores (3\%), and frugivorous (2\%). Regarding birds' feeding guild dissimilarity among habitat types, the result of similarity percentages (SIMPER) analysis and analyses of similarity (ANOSIM) are shown in Table 2. The dissimilarity between $\mathrm{Hg}$ and Lf was mainly linked to insectivores, granivores, and nectarivores with dissimilarity contributions of 58.06, 20.8, and $10.84 \%$, respectively. For the dissimilarities of the two pairs: $\mathrm{Hg}$ vs Ew and $\mathrm{Hg}$ vs $\mathrm{Pl}$, three main feeding guilds were contributing to the highest average dissimilarity. These are granivores, insectivores, and nectarivores. In particular, the presence of granivores in $\mathrm{Hg}$ contributed $52.18 \%$ for group pair of $\mathrm{Hg}$ vs Ew and $48.86 \%$ for group pair of $\mathrm{Hg}$ vs $\mathrm{Pl}$. In group pairs of Lf vs $\mathrm{Ew}$ and $\mathrm{Lf}$ vs $\mathrm{Pl}$, insectivores and granivores contributed more to the dissimilarity for the group pairs. In the cases of group Ew vs $\mathrm{Pl}$, four feeding guilds contributed more 
to the group dissimilarity including insectivores (28.92\%), carnivores (26.53\%), frugivores (21.84\%), and omnivores (11.77\%). From the one-way ANOSIM results, the global $R$ - for group pairs suggests that there was group separation between all corresponding pairs except group $\mathrm{Hg}$ vs Lf with a global $R$-value is 0 , which indicates that no separation between these two groups. In the case of group Lf vs Ew and Ew vs Pl, the global $R$-value is 0.5 and 0.75 , respectively. For three groups: $\mathrm{Hg}$ vs $\mathrm{Ew}, \mathrm{Hg}$ vs $\mathrm{Pl}$, and $\mathrm{Lf}$ vs $\mathrm{Pl}$, the global $R$-value is 1 . This indicates there is group separation between the corresponding group pairs even if in all cases $p$-value $>0.05$ (Table 2).

\section{Discussion}

In this study, order Passeriformes (67.3\%) had the highest number of species from a total of 50 bird species recorded. The result was similar to Shiferaw and Yazezew [34] who surveyed avifauna at Ansas Dam and the surrounding farmland at Debre Berhan Town, Ethiopia. They found a total of 45 bird species belonging to nine orders likewise Passeriformes (37.8\%) was represented the highest number. Species spillover into agricultural matrices is facilitated mainly by land-use type [12].

As found from SIMPER analysis, particular bird species contribute more to the dissimilarities of some groups (sampling habitat) unlike others, for example, Whitebrowed Robin-Chat (Cossypha heuglini), Streaky seedeater (Serinus striolatus), and Village Weaver (Ploceus cucullatus) contributed most to the dissimilarity of the Lf vs Ew and Lf vs Pl group pairs. Other species like African Paradise-Flycatcher (Terpsiphone viridis), Black-Headed Paradise Flycatcher (Terpsiphone rufiventer), and Village Weaver (Ploceus cucullatus) were contributed most to the dissimilarity of Ew vs Pl group pair (more than 40\%). Species occurrence depends on not only a landscape composition but also a patch size [38]. So, habitat heterogeneity is an important environmental determinant of variation in species richness [14].

As ANOSIM significance test shows that there is no significant difference between all group pairs. Additionally, the ordination of non-metric multidimensional scaling (NMDS) was also visually represented a close distance among study sites based on species presenceabsence among study sites (Fig. 4). The lack of significant differences in avian diversity among the study sites might be due to the small surveying area. According to Myers [29] to get data with more statistically significant, the number of study sites and the distance between each, and the sample size (sampling efforts) should be increased. The landscape like linear strips of vegetation fences (live fences) crossing the pastures provides some connectivity to bird populations [17]. This might make homogenous bird species composition along with different adjacent agroforestry habitats types.

In this finding, the insectivores feeding guild had the largest number of species (40\%). This might be due to the best adapter of this feeding guild to the human-modified agricultural area. The ability of understory insectivorous birds to disperse through deforested countryside help them to persist in small fragments habitats [32] As stated by De Bonilla et al. [14] small landscape fragment has as potential key refuges for the most diverse and specialize feeding guilds, such as granivores and insectivores. According to Muñoz-Sáez et al. [27], an important driver of biotic homogenization of the community may be competition exclusion by agricultural adapters. A high abundance of granivores bird species in the $\mathrm{Hg}$ and Lf habitat might partly be associated with diverse seed-producing annual crop species that provided various food types for these birds. Seasonal variations in food sources where farmers plow farmland and annual crop species bloom during the wet and short rain season could be the reason for the relatively higher density of granivores feeding guild. This is similar to Waltert et al. [45] granivorous birds showed the highest species numbers in annual cultures and were significantly fewer species-rich in other habitat types.

As found from SIMPER analysis, some bird feeding functional group contributes more to the dissimilarities of sampling habitats unlike others, for example, In the cases of Ew vs Pl group pair, four feeding guilds contributed more to the group dissimilarity these are insectivores (28.92\%), carnivores (26.53\%), frugivores (21.84\%), and omnivores (11.77\%) whereas the dissimilarity of $\mathrm{Hg}$ vs Lf group pair was mainly linked to insectivores (58.06\%), granivores (20.8\%) and nectarivores (10.84\%). Based on their preference mainly mediated by their choice of food, different functional feeding groups behaved differently [36]. Feeding guild among study sites also not significantly varies. The lack of significant differences might be due to the flight ability of birds along close proximate study sites makes species composition almost homogeneous. A similar previous study suggested that due to their mobile nature, all species of bird supposedly had an equal chance to access all corners of a small area landscape [19]. Several bird species are wideranging, and individuals can move from one study site to another within a short period across a landscape [3].

Our observations and interviews with the gardener of the study area showed that very few of the birds detected in the agroforestry habitats feed on the economically important fruits and the lost cause to the crops by these avian species is insignificant. Instead, as most feeding guilds are insectivores, they seem to feed on insects living in the arboreal structures and on the ground. So, it is 
likely that birds may contribute in important ways to the regulation of insect populations that are the major damaging agents (pests) of the plant.

\section{Conclusion}

In Ethiopia, particularly in the study area, the conservation value of agroforestry for avifauna has not been well documented. Most studies are limited to the national parks and other protected areas. In this study, a total of 50 bird species were recorded in the Kibet town agroforestry system comprising resident species (36\%), wet season visitors (34\%), and dry season visitors (30\%). Order Passeriformes (67.3\%) had the highest number of species followed by order Columbiformes (8.16\%). Two species namely Wattled Ibis (Bostrychia carunculata) and Black-winged Lovebird (Agapornis taranta) were identified as endemic to Ethiopia. Regarding the feeding guilds, the majority of birds' feeding guilds were categorized as insectivores followed by granivores. Generally, one of the main findings of this study is showing the evidence that more insectivore bird species use different types of agroforestry as habitat and foraging sites.

\section{Recommendations}

$>$ Our finding provides strong evidence that humanmodified landscape is successful at attracting more insect-eating birds that might serve as biological control of pests;

$>$ Mosaic of agricultural areas with a large multipurpose tree might sustain a considerable proportion of the bird fauna;

$>$ The Government should give support to simplify the access of tree seed and germplasm to the gardener.

\section{Supplementary Information}

The online version contains supplementary material available at https://doi. org/10.1186/s40693-021-00106-2.

Additional file 1. Bird species recorded in the study area during wet and dry seasons.

\section{Acknowledgments}

We would like to acknowledge Wolaita Sodo and Werabe Universities for their support. We would like to gratify for the precious time and energy that the editors and the three reviewers of Revista Chilena de Historia Natural Journal have devoted to giving us constructive comments for the improvement of our manuscript. Lastly, we would like to acknowledge Mr. Jemal Selman for mapping the study area.

\section{Authors' contributions}

All authors contributed to the study's conception and design. Material preparation, data collection, and analysis were performed by Hussein Yasin and Wondimagegnehu Tekalign. The first draft of the manuscript was written by Hussein Yasin. The draft manuscript was commented on and approved by Wondimagegnehu Tekalign. The author(s) read and approved the final manuscript.

\section{Funding}

This research did not receive any specific grant from funding agencies in the public, commercial, or not-for-profit sectors.

\section{Availability of data and materials}

Data sharing is not applicable to this manuscript as no datasets were generated or analyzed during the current study.

\section{Declarations}

\section{Ethics approval and consent to participate}

This study was conducted in accordance with the declaration of Helsinki that provides guidance for the researcher to protect research subjects. The study was approved by the Institutional Research Review Board (IRB) of Wolaita Sodo University. The consent to participate is not applicable to this research.

\section{Consent for publication}

All authors agreed to the public this original research work.

\section{Competing interests}

The authors declare that they have no competing interests.

\section{Author details}

${ }^{1}$ Department of Biology, College of Natural and Computational Sciences, Werabe University, Werabe, Ethiopia. ${ }^{2}$ Department of Biology, College of Natural and Computational Sciences, Wolaita Sodo University, PO Box 138, Wolaita Sodo, Ethiopia.

Received: 6 July 2021 Accepted: 22 December 2021

Published online: 12 January 2022

\section{References}

1. Achiso Z, Masebo N. Parkland agroforestry practices on biodiversity conservation-a review. SSR Inst Int J Life Sci. 2019;5:2412-20.

2. The Nature Conservancy. Assessing Linkages between Agriculture and Biodiversity in Central America: Historical Overview and Future Perspectives. Mesoamerican \& Caribbean Region, Conservation Science Program. The Nature Conservancy (TNC). San José, Costa Rica, 2005.

3. Aney WC. Effects of patch size on bird communities of remnant oldgrowth pine stands in western Montana; 1984.

4. Ash J, Atkins J. Birds of Ethiopia and Eritrea: an atlas of distribution. London: Christopher Helm; 2009.

5. Assandri G, Bogliani G, Pedrini P, Brambilla M. Insectivorous birds as 'nontraditional'flagship species in vineyards: applying a neglected conservation paradigm to agricultural systems. Ecol Indic. 2017;80:275-85.

6. Aynalem S, Bekele A. Species composition, relative abundance, and distribution of bird fauna of riverine and wetland habitats of Infranz and Yiganda at the southern tip of Lake Tana, Ethiopia. Trop Ecol. 2008:49:199-209.

7. Bantihun A. Opportunities and challenges of adopting home garden agroforestry practices in Ethiopia. Agri Res Tech. 2019;20:132-42.

8. Barve SS. Responses showed by bird communities to teak plantations in Sagar Forest division. Rajkot: Karnataka. Dissertation Submitted to University of Saurashtra; 2009. https://www.researchgate.net/publication/27627 2672. Accessed 5 Jan 2021

9. Behera LK, Nayak MK, Gunaga RP, Dobriyal MJ, Patel DP. Land-use system agroforestry for biodiversity conservation of native species. Multilog Sci. 2015:4:125-30.

10. Birhane E. A final Report Agroforestry Governance in Ethiopia. The Federal Democratic Republic of Ethiopia. Ministry of Agriculture and Natural Resources. Addis Ababa, Ethiopia; 2014.

11. Bishaw $B$, Abdelkader A. Agroforestry and community forestry for rehabilitation of degraded watersheds on the Ethiopian highlands. Addis Ababa: International Symposium on Contemporary Development Issues in Ethiopia; 2003. 
12. Boesing AL, Nichols E, Metzger JP. Effects of landscape structure on avian-mediated insect pest control services: a review. Landsc Ecol. 2017:32(5):931-44.

13. Clarke KR. Non-parametric multivariate analyses of changes in community structure. Aust J Ecol. 1993;18:117-43.

14. De Bonilla EPD, León-Cortés JL, Rangel-Salazar JL. Diversity of bird feeding guilds in relation to habitat heterogeneity and land-use cover in a humanmodified landscape in southern Mexico. J Trop Ecol. 2012;28:369-76.

15. Doilicho B. Population and major livelihoods in Silte and Dalocha Woredas of Silte zone. In: Working papers on population and land-use change in Central Ethiopia. Thesis and reports submitted to Addis Ababa University, Ethiopia; 2017

16. Engelen D. Comparing avifauna communities and bird functional diversity of forest and farmland in southwest Ethiopia; 2012.

17. Estrada A, Cammarano P, Coates-Estrada R. Bird species richness in vegetation fences and in strips of residual rain forest vegetation at LoS Tuxtlas, Mexico. Biodivers Conserv. 2000;9:1399-416.

18. FAO. Forests and Water: Valuation and Payments for Forest Ecosystem Service. United Nations publication issued by the Economic Commission for Europe (ECE), United Nations, Geneva, Switzerland, 2018.

19. Greenler S, Ebersole JJ. Bird communities in tropical agroforestry ecosystems: an underappreciated conservation resource. Agrofor Syst. 2015;89(4):691-704.

20. Hammer $\varnothing$, Harper DAT, Ryan PD. PAST: paleontological statistics software package for education and data analysis. Palaeontol Electron. 2001;4(1):9 http://www.svt.ntnu.no/geo/Doklager/Acta/serie_a_19_beyene.pdf.

21. Kassie GW. Agroforestry and land productivity: evidence from rural Ethiopia. Cogent Food Agric. 2006;2:1-17.

22. Legendre P, Gallagher ED. Ecologically meaningful transformations for ordination of species data. Oecologia. 2001;129:271-80.

23. Leaver J, Carstens JC, Cherry MI. Harvesting of forest products and implications for Afrotemperate bird communities in a montane forest of the Eastern Cape, South Africa. For Ecosyst. 2019;6(1):1-15.

24. McDermott ME. The contribution of agroforestry systems to bird conservation in the Andes. Dissertation. Colombia: The Ohio State University; 2014.

25. Mcneely JA, Schroth G. Agroforestry and biodiversity conservation - traditional practices, present dynamics, and lessons for the future. Biodivers Conserv. 2006;15:549-54.

26. Mekonen S, Chinasho A, Berhanu K, Tesfaye S. Threats and conservation challenges of wildlife in Harenna Forest, Harenna Buluk District, south East Ethiopia. Int J Biodivers Conserv. 2017;9:246-55.

27. Muñoz-Sáez A, Heaton EE, Reynolds M, Merenlender AM. Agricultural adapters from the vineyard landscape impact native oak woodland birds. Agric Ecosyst Environ. 2020;300:106960.

28. Muñoz-Sáez A, Perez-Quezada JF, Estades CF. Agricultural landscapes as habitat for birds in central Chile. Rev Chil Hist Nat. 2017;90:1-12.

29. Myers S. Avian diversity and abundance in three different vegetative landscapes around a shade-grown coffee plantation on Mount Totumas, Chiriquí Highlands, Panamá; 2018

30. Norfolk O, Jung M, Platts PJ, Malaki P, Odeny D, Marchant R. Birds in the matrix: the role of agriculture in avian conservation in the Taita Hills, Kenya. Afr J Ecol. 2017;55(4):530-40.

31. Philpott SM, Armbrecht L. Biodiversity in tropical agroforests and the ecological role of ants and ant diversity in predatory function. Ecol Entomol. 2006;31:369-77.

32. Sekercioglu CH, Ehrlich PR, Daily GC, Aygen D, Goehring D, Sandí RF. The disappearance of insectivorous birds from tropical forest fragments. Proc Natl Acad Sci. 2002;99(1):263-7.

33. Sekercioglu $\mathrm{CH}$. Bird functional diversity and ecosystem services in tropical forests, agroforests, and agricultural areas. J Ornithol. 2012;153:153-61.

34. Shiferaw A, Yazezew D. Diversity, distribution, and relative abundance of avifauna at Aransas Dam and surrounding farmland site Debre Berhan town, Ethiopia. Avian Biol Res. 2021;14:8-17.

35. Shannon CE, Wiener N. The mathematical theory of communication. Urbana: The University of Illinois; 1949

36. Sohil A, Sharma N. Assessing the bird guild patterns in heterogeneous land use types around Jammu, Jammu, and Kashmir, India. Ecol Process. 2020;9(1):1-5

37. Somerfield PJ, Clarke KR, Gorley RN. Analysis of similarities (ANOSIM) for 2-way layouts using a Generalised ANOSIM statistic, with comparative notes on Permutational Multivariate Analysis of Variance (PERMANOVA). Austral Ecol. 2021;46:1-15. https://doi.org/10.1111/aec.13059.
38. Steel ZL, Steel AE, Williams JN, Viers JH, Marquet PA, Barbosa O. Patterns of bird diversity and habitat use in mixed vineyard-matorral landscapes of Central Chile. Ecol Indic. 2017:73:345-57.

39. Swallow B, Boffa JM, Scherr SJ. The potential for agroforestry to contribute to the conservation and enhancement of landscape biodiversity: World Agroforestry Centre and Sara J. Scherr, Forest Trends; 2006.

40. Takele S, Endale G. Species' composition and relative abundance of lakeshore bird species around Lake Hawassa, Ethiopia. Int J Biodivers Conserv. 2019:11(175):182

41. Udawatta RP, Rankoth LM, Jose S. Agroforestry and biodiversity. Sustain. 2019;11:2-22.

42. UMCA. Agroforestry for ecosystem services. Annual report: research, education, and outreach. The Center for Agroforestry, University of Missouri, Columbia, 2011.

43. UMCA, Training manual for applied agroforestry practices: The Center for Agroforestry, University of Missouri, Columbia; 2015.

44. Verner J. Assessment of counting techniques. In: Johnston RF, editor. Current ornithology, vol. 2. Boston: Springer; 1985.

45. Waltert M, Bobo KS, Sainge NM, Fermon H, Hlenberg MM. From forest to farmland: habitat effects on Afrotropical forest bird diversity. Ecol Appl. 2005;15:1351-66.

46. Williams JG, Arlott N. Collins field guide: birds of eastern Africa. London: HarperCollins Publisher; 1995.

47. Withers MB, Hosking D. Common birds of East Africa-Collins safari guides. London: HarperCollins Publisher; 1996.

\section{Publisher's Note}

Springer Nature remains neutral with regard to jurisdictional claims in published maps and institutional affiliations.

Ready to submit your research? Choose BMC and benefit from

- fast, convenient online submission

- thorough peer review by experienced researchers in your field

- rapid publication on acceptance

- support for research data, including large and complex data types

- gold Open Access which fosters wider collaboration and increased citations

- maximum visibility for your research: over 100M website views per year

At BMC, research is always in progress.

Learn more biomedcentral.com/submissions 